\title{
THE ECONOMIC IMPACT OF A RURAL LAND TAX ON SELECTED commercial farms in Kwazulu-Natal, South Africa
}

MAG Darroch, RB Lee and GF Ortmann

School of Agricultural Sciences and Agribusiness, University of KwaZulu-Natal

\begin{abstract}
This study investigates the economic impact of a land tax implemented under the Local Government Municipal Property Rates Act No. 6 of 2004 on commercial farms using five case studies with fiveyear data sets in the Mtonjaneni and Umgeni municipal districts of KwaZulu-Natal. The case of farms' ability to pay annual rates between 0.25 per cent and 1 per cent of the value of improved land using real annual economic profit with and without rebates of up to 70 per cent proposed by the Department: Provincial and Local Government ranged from zero to five out of five years, with a mean of two out of five years. A 2 per cent land tax rate with such rebates could also be financed only in two out of five years on average. These results suggest that proposed annual land tax rates of 1.5 per cent (Mtonjaneni) or 1 per cent (Umgeni) on these specific farms would markedly reduce the incentive to invest in farm improvements.
\end{abstract}

JEL H22, 71

\section{1}

\section{Introduction}

Since the early 1990s, the South African (SA) Government has considered the implementation of a rural land tax, as reflected by 15 drafts of the proposed Local Government Property Rates Bill. This Bill has now been enacted into legislation as the Local Government Municipal Property Rates Act No. 6 of 2004 (hereafter referred to as "the LGMPRA") (Department: Provincial and Local Government (DPLG), 2004a). President Mbeki signed the LGMPRA into effect on 2 July 2005 (SA Government Gazette No. 27720, 2005). Prior to that date, farm land in South Africa was not subject to property taxes levied by municipalities. The new LGMPRA however, incorporates all previously unrated land into municipal boundaries, so that farm land that was not rated under the old municipal ordinances is now liable to pay a land tax (DPLG, 2004a).

The power for SA municipalities to levy a tax on land stems from Section 229 of the SA Constitution, which guarantees "rates on property" as "an autonomous source of revenue for municipalities" (Franzsen, 2000: 1). In terms of Section 229 of the SA Constitution, a municipality may impose rates on property and surcharges on fees for services provided by or on behalf of the municipality. However, Section 229(2)(a) of the SA Constitution states that a municipality may not exercise its power to levy rates on property in a way that would materially and unreasonably prejudice (a) national economic policies; (b) economic activities across its boundaries; or (c) the national mobility of goods, services, capital or labour (DPLG 2004a: 28).

In South Africa, the land tax is intended to "provide local government with access to a sufficient and buoyant source of revenue to fulfill its developmental responsibilities" (DPLG, 2004b: 5). There is a relatively limited amount of published literature that analyses the potential economic impact of a land tax on commercial farms in South Africa. Nieuwoudt $(1990 ; 1995)$ noted that a land tax is likely to reduce land rents, and hence cause lower farm land values and discourage investment on farms. Franzsen $(1995 ; 2000)$ concluded that the implementation of a land tax on commercial 
farms could be administratively feasible to levy, assess and collect if it is left to each individual tax jurisdiction to decide after consultation, and in light of its own peculiar circumstances and conditions, which method(s) of valuation and what tax rate to use. Van Schalkwyk et al. (1994) reported that a land tax may reduce land values, which in turn would affect the security value of land pledged against loans from financial institutions. No published peer-reviewed study in South Africa, however, has estimated the economic impact of a land tax on commercial farms using actual accounting and economic data for specific individual farms.

The aim of this study, therefore, is to estimate the potential impacts of a land tax on selected commercial farms in KwaZulu-Natal (KZN) using farm-specific annual data for the period 2001-2006. The study assesses how a land tax affects farm economic profit (the return to risk and land) that shows the ability of the farm to pay a land tax after accounting for the opportunity cost of resources other than land used on the farm. A Residual Income Methodology (RIM) is developed to estimate the annual and mean economic profit for five selected commercial farms in KZN within the Mtonjaneni and Umgeni municipal districts that have different farming enterprises. Sensitivity analysis is then used to assess whether or not the annual economic profit can finance a range of land tax rates that these municipalities could apply to the market value of land and fixed improvements (the basis for valuing land in terms of the LGMPRA (DPLG, 2004a)). This range includes the annual rates of 1.5 per cent and 1 per cent, respectively, proposed by these two municipalities. The sensitivity analysis also accounts for potential land tax rebates as proposed by the DPLG in the "Generic Rates Policy Format (GRPF)" guidelines (DPLG, 2004c). The paper is organised as follows: Section 2 describes the key provisions of the new LGMPRA, while Section 3 summarises the GRPF guidelines. Section 4 outlines the economic effects of a land tax, and Section 5 describes the study research methodology. Section 6 presents the results of the five case studies. A concluding section discusses some management and policy implications of the results.
2

\section{Key provisions in the \\ LGMPRA No. 6 of 2004}

The key provisions in the LGMPRA for this study pertain to the criteria that municipalities must use to value and rate farm land.

\subsection{Designation of municipal valuers and method of property valuation}

Before the date of property valuation every municipality must designate a person as a municipal valuer; this person may be a municipal official or a valuer who is in private practice. If the valuer is in private practice, the municipality must receive tenders for the intended valuation work so as to follow an open, competitive and transparent process as per Chapter 11 of the Municipal Finance Management Act. The municipal valuer must determine a "market value" for all properties within that municipality and prepare a valuation role for these properties. Market value is defined in Section 46(1) of the LGMPRA as "the amount the property would have realized if sold on the date of valuation in the open market by a willing seller to a willing buyer" (DPLG, 2004c: 50). Professional independent valuers must be persons registered as professional valuers or professional associated valuers in terms of the Property Valuers Profession Act, 2000 (Act No. 47 of 2000) and know how to value properties which have not yet been sold using the "willing seller to a willing buyer" principle (DPLG, 2004a: 2). Section 46(1) of the LGMPRA further states that "in determining the market value of a property used for agricultural purposes, the value of any annual crops or growing timber on the property that have not yet been harvested as at the date of valuation must be disregarded for purposes of valuing the property" (DPLG, 2004a: 50). A valuation roll will remain valid for up to four financial years, after which it must be updated (DPLG, 2004a: 40).

\subsection{Determination of the land tax rate}

The financial liabilities for municipal property rates are calculated by multiplying the market value of immovable property by a cent amount 
in the rand that a municipal council has determined. This amount is supposed to be decided by that council taking into account public comments, submissions and inputs on the council's draft rates policy and budget that is subjected to the process of community participation (DPLG, 2004b: 2). The critical determinant of how much property owners will pay is the amount in rands that each municipal council will determine for various property categories. In addition, the LGMPRA does not give the right to substantial increases in the total revenue needs of municipalities, nor does it set the cent amount in the rand. Each municipality will apparently continue to set and collect property rates in an amount sufficient to meet its needs, taking into account the likely impact of rates on local economic development, ratepayers and their ability to pay such rates (DPLG, 2004c: 3). In this regard, it must be noted that most of the developed countries that are South Africa's main trading partners tend to levy annual land taxes on farms at rates below 1 per cent, whereas local municipalities tend to have higher rates - for example the Mtonjaneni and Umgeni municipalities have proposed rates of 1.5 per cent and 1 per cent, respectively (Darroch, 2003; Barnsley, 2006; The Witness, 2007). Farmers in developed countries (except New Zealand and Australia) also receive higher levels of agricultural support from their governments than do most SA commercial farmers (apart from tariff protection afforded to several industries such as the SA sugar industry) (Organisation for Economic Cooperation and Development, 2006).

The LGMPRA contains what are intended to be checks and balances to protect property owners if a land tax rate levied by a municipality is materially and unreasonably prejudicing national economic policies, economic activities across municipal boundaries, and the national mobility of goods, services and capital. If the Minister for Provincial and Local Government is convinced by evidence to this effect, the Minister must, in terms of Section 16(2)(a) of the LGMPRA, and after notifying the Minister of Finance, gazette a notice to the relevant municipality that the cent amount in the rand must be limited to the amount specified in the notice (DPLG, 2004a: 28). Commercial farmers will, therefore, have to provide such evidence if they want to appeal against the land tax rates levied by local municipalities.

\subsection{Compulsory phasing-in of certain rates}

Section 21 of the LGMPRA requires municipalities to "phase-in" land tax rates levied on newly rateable property over three financial years. This refers to any property on which property rates were not levied before the end of the financial year preceding the date on which the LGMPRA took effect. The phasingin discount must be at least 75 per cent of the land tax rate in the first year that a municipality implements the LGMPRA, at least 50 per cent in the second year, and at least 25 per cent in the third year. The full land tax rate then applies from the fourth year onwards (DPLG, 2004a: 33-34).

\subsection{Property rate exemptions, reductions and rebates}

In addition to the mandatory prohibitions on rating described above, Section 3(4) of the LGMPRA enables municipalities to grant exemptions from, rebates on, and reductions in property rates based on local conditions and circumstances. Owners of agricultural properties who are bona fide farmers qualify for such relief measures (see Section 15(2)(f) of the LGMPRA (DPLG 2004a: 28)). The LGMPRA does not specify the extent of these measures, but guidelines for setting rebates for the owners of agricultural land are proposed in the GRPF. These guidelines are discussed in section 3 of this paper. A municipality also may not levy rates on a property belonging to a land reform beneficiary or his or her heirs for 10 years from the date on which such beneficiary's title was registered (DPLG, 2004a: 30). 
3

\section{Guidelines proposed by the DPLG for land tax rebates for commercial farms}

Section 3(4) of the LGMPRA requires that a municipality must consider the following criteria in developing a policy for annual exemptions, rebates and reductions for properties used for agricultural purposes: (a) the extent of services it provides in respect of such properties; (b) the contribution of agriculture to the local economy; (c) the extent to which agriculture assists in meeting the municipality's service delivery and development obligations; and (d) the contribution of agriculture to farm workers' social and economic welfare. The guidelines for such criteria proposed in the GRPF (DPLG, 2004c) are outlined in the following three sections.

\subsection{Extent of municipal services provided to agricultural properties}

- 7.5 per cent rebate, if there are no municipal roads next to the property.

- 7.5 per cent rebate, if there is no municipal sewerage to the property.

- 7.5 per cent rebate, if there is no municipal electricity to the property.

- 20 per cent rebate, if water is not supplied by the municipality.

- 7.5 per cent rebate, if the municipality provides no refuse removal (DPLG, 2004c: 11).

\subsection{The contribution of agriculture to the local economy}

An annual rebate of up to 5 per cent is proposed if an agricultural property contributes substantially to job creation, and the salaries/ wages of its farm workers are reasonable, e.g., if they meet the minimum standards set by the Government (minimum wage) or if they are in line with the industry average (DPLG, 2004c: 12).

\subsection{Extent to which agriculture assists the municipality in meeting its service delivery and development obligations}

- 5 per cent rebate, if the owner is providing permanent residential property to the farm workers and such property is registered in the name of these farm workers; proof must be provided.

- 5 per cent rebate, if such residential properties are provided with potable water.

- 5 per cent rebate, if the farmer electrifies such residential properties of farm workers.

- 5 per cent rebate, if the farmer is availing his land/buildings to be used for cemetery, education and recreational purposes of the farm workers' children and nearby community in general, etc. (DPLG, 2004c: 12).

Under the three sets of guidelines, a farmer that meets all of the proposed requirements would receive a maximum annual land tax rebate of 75 per cent. The RIM for each of the five case study farms accounts for these proposed rebates where applicable. Section 4 outlines the economic effects of a land tax on farm land as background for the RIM.

\section{4}

\section{Outline of the economic effects of a land tax on farm land}

This section outlines the potential effects of a land tax on farm land rents and investment, the advantages and disadvantages of a land tax, and the concept of the capitalisation of a land tax.

\subsection{Effects of a land tax on farm land rents and investment}

Nieuwoudt (1995, citing Pasour (1975)) notes that a rural land tax on the improved value of land (in the long run) falls on new investment and as such will be a disincentive to future investment in land improvements. A land tax reduces current operating returns to land (cash rents), and thereby reduces the incentive to invest in new improvements. This is likely 
to reduce future food production and export earnings, and increase food prices in the long run. A land tax is thus unlikely to bring idle land into use. Other disadvantages of a land tax include: (a) administration is costly as all properties need to be appraised individually and regularly; (b) in practice it is almost impossible to exclude all improvements from the tax; (c) the tax is a flat rate tax and not progressive; and (d) the tax is the same in relatively higher income years and relatively lower income years during a given valuation cycle, although it may be possible to defer the tax and incur interest charges. The land tax is thus a fixed cost as it cannot be shifted and has to be paid by the farmer regardless of what is produced on the farm. Against these disadvantages, the following are advantages of a land tax: (a) evasion and avoidance are not possible; (b) farmers need not keep records on costs and incomes as required for Value Added Tax and income tax reporting; (c) it is a wealth tax; and (d) it may more effectively tax the wealthy landowner who with the assistance of tax experts can plan to avoid income taxes (Lindholm, 1972; Van Schalkwyk et al., 1994; Franzsen, 1995; Nieuwoudt, 1995; Olsen, 2004: 87).

\subsection{Capitalisation of a land tax}

Pasour (1973; 1975) and Barry et al. (2000) show that land taxes or increases in land taxes in the United States were capitalised (discounted) into lower farm land values. The current market value of farm land, $\mathrm{V}_{0}$, can be estimated by capitalising the expected annual real earnings from that land (cash rents), $\mathrm{R}_{0}$. If $\mathrm{R}_{0}$ are expected to grow over time at a real rate of $g$ per cent, $V_{0}$ is estimated by the constant growth model (if $\mathrm{g}$ is constant) as (Barry et al., 2000):

$\mathrm{V}_{0}=\mathrm{R}_{0}(1+\mathrm{g}) /\left(\mathrm{i}_{\mathrm{t}}-\mathrm{g}\right)$

where $i_{t}$ is the expected real interest rate. Reworking equation (4.1) gives:

$\left(\mathrm{i}_{\mathrm{t}}-\mathrm{g}\right) /(1+\mathrm{g})=\mathrm{R}_{0} / \mathrm{V}_{0}$

Equation (4.2) implies that there is a constant ratio between $\mathrm{R}_{0}$ and $\mathrm{V}_{0}-$ a rise (fall) in $\mathrm{R}_{0}$ causes a proportional rise (fall) in $\mathrm{V}_{0}$. Nieuwoudt (1987: 10) and Ortmann (1987: 295) both state that the long-run average rental rate of return for land in SA agriculture $\left(\mathrm{R}_{0} / \mathrm{V}_{0}\right)$ is about 5 per cent. Rents show the true profits realised from land after considering all costs, including risk and management, where rent is the "payment made per unit of time to owners of property for the use of their land and buildings" (Ortmann, 1987: 249). If a land tax of 1 per cent of $V_{0}$ is fully capitalised, $\mathrm{R}_{0}$ after the land tax $=5$ per cent -1 per cent $=4$ per cent, a drop of 20 per cent. A fall in $\mathrm{R}_{0}$ from, say, 100 rand, to 80 rand, thus means that $\mathrm{V}_{0}$ falls from $100 / 0.05=2000$ rand to $80 / 0.05=1600$ rand, or by $400 / 2000$ $=20$ per cent.

Land values are thus expected to fall by the same percentage as land rents if a land tax is fully capitalised into lower land values. Full capitalisation, however, is unlikely as the supply of improved farmland is likely to be highly inelastic rather than perfectly inelastic in the long-run. The reason is that improvements such as draining, clearing, fencing, irrigation, new pastures, etc. take time to develop in response to higher expected rents. Such changes are thus likely to be small relative to the total quantity of improved farmland available during any time period (Pasour, 1975). This implies that a relatively small share of the land tax will be "shifted" to consumers in the form of higher prices due to less future investment in land improvements. In addition, if the proceeds from a land tax are used to improve municipal infrastructure, such as the upgrading of roads, $\mathrm{R}_{0}$ and hence $\mathrm{V}_{0}$ could rise, thereby partially offsetting the fall in net rent and $\mathrm{V}_{0}$ caused by the land tax (Pasour, 1973). The capitalisation of lower expected net rents into lower expected land values implies that the RIM described in section 5.3 below must account for the negative impact of the land tax on rental returns to land.

\section{5}

Research methodology

This section describes the case study farms, study data collection and the RIM framework. 


\subsection{Target commercial farms in KZN}

Due to cost and time constraints, and the confidential nature of the required data, the selected commercial farms were drawn from farmers in the Mtonjaneni and Umgeni municipal districts of KZN that were prepared to provide the annual data required for the RIM. The Mtonjaneni municipal district office is based in Melmoth in Zululand, some $270 \mathrm{~km}$ north of Pietermaritzburg, the capital city of $\mathrm{KZN}$. The Umgeni municipal district office is based in Howick, which is about $35 \mathrm{~km}$ northwest of Pietermaritzburg. The KZN province has a diverse commercial farming sector operating enterprises such as poultry, livestock, sugarcane, timber, vegetable, maize, and dairy (Wikipedia, 2006). The five commercial farms used to develop the case studies in this paper differ in the main enterprises.

Case Study 1 is an 816 hectare (ha) sugar cane and timber farm in the Mtonjaneni municipal district. Case Study 2 describes an intensive poultry (egg) farm with some maize (170 ha in total area), while Case Study 3 is an intensive dairy farm on 434 ha. Case Study 4 applies to 239 ha of farm land that is leased out for intensive vegetable production, maize and grazing. Case Study 5 is a mixed enterprise farm producing maize, potatoes, sheep, cattle and poultry, spanning 374 ha. Case study farms 2 to 5 are situated in the Umgeni municipal district. These five farms were chosen as their owners were: (a) well-established (operating for over 10 years); (b) able to provide relevant, accurate and audited accounting data for the last five to six years; (c) willing to release confidential accounting and economic data; and (d) operating typical farm enterprises found in KZN. Given that land reform beneficiaries receive a 10 -year exemption from the payment of property rates, no "land reform" case study was analysed.

\subsection{Study data collection}

Data were collected from each farmer using face-to-face interviews and a questionnaire designed to estimate the size of annual land tax rebates using the proposed DPLG GRPF guidelines discussed in section 3 . The accounting data were drawn from the farm income and cash flow statements and balance sheets. These data were analysed using the RIM described in section 5.3 to estimate the annual return to risk and land (a proxy for rent) for each farm during 2001-2006 if available. The market value of land and fixed improvements for each farm (including the homestead, and excluding the value of standing crops) was estimated by independent professional valuers who requested to remain anonymous and not be cited in this paper. These market valuations are listed in each municipality's valuation roll and were conducted in accordance with the LGMPRA definition of market value (see section 2.1) using the comparable sales method. The research questionnaire contained questions about the extent of municipal services received by the farm; job creation and wage levels on each farm, and services provided to staff; and the farmer/ land owner's estimated opportunity cost of management (net revenue forgone from his/her next best occupation (Olsen, 2004)).

\subsection{Empirical analysis using the RIM framework}

Meaningful conclusions about how to allocate resources need to be drawn from the expected economic, and not accounting, performance of farms (Aggarwal, 2001). The RIM is useful in this regard as it reduces revenue after accounting costs and income tax by a charge for the opportunity cost of management that is employed to produce the income. This yields an estimate of economic profit (Hawawini et al., 2001: 11) that is a proxy for the current annual operating return to risk and land generated by a farming activity. Economic profit gives farmers and policy makers a better understanding of whether a farm can afford different levels of annual land tax - a farm with a high accounting profit may not necessarily have a high economic profit. The RIM in this paper is adapted from Mepham (1980), Kay \& Edwards (1999), and O'Hanlon \& Peasnell (2004), as illustrated in Appendix 1 for Case Study 1 (the RIMs for the other four case studies are not shown due to the word limitation on this paper, but are available from the authors on request). The RIM first estimates annual nominal accounting 
profit as farm revenue less fixed costs and variable costs, plus other receipts (if any), for each year during 2002-2006. Under fixed costs, the annual depreciation charge is adjusted to current cost terms using the relevant Machinery and Implement index for each year (see SA Department of Agriculture (2006: 101)). This implies that the operational capacity of each case study farm is sustained by adequate provision of funds for the replacement of machinery and implements (Faul et al., 1981).

Annual nominal accounting profit (loss) is then expressed in real terms after income tax using the SA Consumer Price Index (CPI) with 2006 as base year (Statistics SA, 2006) and income tax rates as reported by the SA Revenue Service (SARS) (SARS, 2006). Deducting the real opportunity cost of management after income tax then gives an estimate of the annual real economic profit (return to risk and land). The opportunity cost or value of operator labour and management is what the operator (farmer) could receive in a non-farm job that requires similar labour and management skills (Olsen, 2004: 209). If this opportunity cost component is ignored, annual farm profit will be overstated and this figure should then be interpreted as the "estimated return to management and profit" (Kay \& Edwards, 1999: 168). In addition, if the opportunity cost of management is not covered (negative economic profit), the farmer would have an incentive to shift his resources out of the current farm enterprises into other uses (Doll \& Orazem, 1984). To allow for uncertainty in obtaining off-farm employment, the opportunity cost of management after income tax in this paper is given by each farmer's estimate of the real annual net income after income tax that he/she could earn in his/her best alternative non-farm job multiplied by his/her subjective estimate of the probability of actually securing that job. The annual real economic profit (return to risk and land) ignores any (non-cash) capital gains due to the appreciation (if any) in value of improved farm land - it estimates the current operating returns available to pay the land tax after all resources other than land have received payment.

The annual real return to risk and land expressed as a percentage of the market value of land and fixed improvements as of 2006 gives the rate of return to risk and land. Following Barnard \& Nix (1979: 530), the mean annual real economic profit and rate of return to risk and land for each case study over several seasons (2001-2006 if available) is estimated to effectively compare farm financial results. Sensitivity analysis is then used to assess whether or not the annual and mean returns to risk and land can fund different rates of annual land tax ranging from 0.25 per cent to 5 per cent (the latter being the estimated average annual rate of return to farm land in South Africa (Nieuwoudt, 1987; Ortmann, 1987; Darroch, 2003)). The sensitivity analysis also accounts for the effects of proposed annual land tax rebates under the GRPF guidelines, and hence shows each farm's ability to pay each land tax rate with and without the applicable rebate(s). For case studies 2 to 5 , it also includes the effects of the 50 per cent rebate that has been proposed by the Umgeni Municipality (despite the GRPG guidelines) for agricultural properties (Lee, 2007). Case Study 1 in the Mtonjaneni municipal district is subject to the three-year phasing-in period for the land tax, while case studies 2 to 5 in the Umgeni municipality are no longer considered as "previously unrated land", and do not qualify for phasing-in (Barnsley, 2006).

\section{6}

\section{Results}

\subsection{Case study 1}

This sugarcane and timber farm (real market value of R7 500 000) qualifies for a 70 per cent land tax rebate (all GRPF rebate guideline criteria except for providing permanent housing to farm workers are met). Table 1 summarises key annual accounting and economic data, and Table 2 shows the annual land tax due with and without the rebate for tax rates between 0.25 per cent and 5 per cent. Table 3 tracks the land tax amount due over the three-year phasing-in period for the 1.5 per cent rate proposed by the Mtonjaneni Municipality. After four years with no rebate the annual land tax is R112 000, while a 70 per cent rebate reduces the annual land tax to R33 750 . 


\section{Table 1}

Key measures: Sugarcane and timber farm, Mtonjaneni municipality, KZN (2006=100)

\begin{tabular}{|l|c|c|c|c|c|c|}
\hline Measure & $\mathbf{2 0 0 6}$ & $\mathbf{2 0 0 5}$ & $\mathbf{2 0 0 4}$ & $\mathbf{2 0 0 3}$ & $\mathbf{2 0 0 2}$ & Mean \\
\hline Nominal accounting profit (R) & 1218115 & 170790 & 496989 & 1169107 & 1025108 & 816022 \\
\hline $\begin{array}{l}\text { Real accounting profit before } \\
\text { income tax (R) }\end{array}$ & 1218115 & 178838 & 537867 & 1283323 & 1190602 & 881748 \\
\hline $\begin{array}{l}\text { Real accounting profit (loss) after } \\
\text { income tax (R) }\end{array}$ & 773869 & 134924 & 352744 & 792201 & 708279 & 552403 \\
\hline $\begin{array}{l}\text { Real opportunity cost of } \\
\text { management (R) }\end{array}$ & 405000 & 405000 & 405000 & 405000 & 405000 & 405000 \\
\hline Real economic profit (R) & 368869 & -270076 & -52256 & 387201 & 303279 & 147403 \\
\hline Return to risk and land (\%)1 & $4.92 \%$ & $-3.60 \%$ & $-0.70 \%$ & $5.16 \%$ & $4.04 \%$ & $1.96 \%$ \\
\hline
\end{tabular}

${ }^{1}$ Note: Return to risk and land $(\%)=$ Real economic profit/real value of land and fixed improvements (R7 500000 ).

\section{Table 2}

Annual land tax with and without a rebate: Sugarcane and timber farm, Mtonjaneni municipality, KZN (2006=100)

\begin{tabular}{|l|c|c|c|c|c|c|c|c|}
\hline Land tax rate & $\mathbf{0 . 2 5 \%}$ & $\mathbf{0 . 5} \%$ & $\mathbf{1 \%}$ & $\mathbf{1 . 5 \%}$ & $\mathbf{2 \%}$ & $\mathbf{3 \%}$ & $\mathbf{4 \%}$ & $\mathbf{5 \%}$ \\
\hline $\begin{array}{l}\text { Amount payable } \\
\text { (No rebate) (R) }\end{array}$ & 18750 & 37500 & 75000 & 112500 & 150000 & 225000 & 300000 & 375000 \\
\hline $\begin{array}{l}\text { Amount payable } \\
\text { (70\% rebate) (R) }\end{array}$ & 5625 & 11250 & 22500 & 33750 & 45000 & 67500 & 90000 & 112500 \\
\hline
\end{tabular}

\section{Table 3}

Annual land tax over the four-year phasing-in period for a 1.5 per cent tax rate: Sugarcane and timber farm, Mtonjaneni municipality, KZN (2006 = 100)

\begin{tabular}{|l|c|c|}
\hline Period & With No Rebate & With a 70\% Rebate \\
\hline Year 1: 75\% reduction (R) & 28125 & 8436 \\
\hline Year 2: $50 \%$ reduction (R) & 56250 & 16875 \\
\hline Year 3: $25 \%$ reduction (R) & 84375 & 25213 \\
\hline Year 4: Full rate applies (R) & 112500 & 33750 \\
\hline
\end{tabular}

The five-year mean return to risk and land for Case 1 implies that an annual land tax of $1.96 \%$ would, on average, tax away all economic profit. Given the fluctuating five-year trend, estimated annual economic profit could probably finance the proposed 1.5 per cent annual land tax in two out of four years during the phasing-in period. In the long-term after the phasing-in period is over, estimated annual economic profit can meet all land tax scenarios from 0.25 per cent up to 4 per cent with no rebate, and 5 per cent with GRPF rebate, in three out of five years. A land tax rate of 5 per cent with no rebate can only be met in one year (2003) when it will almost deplete real economic profit. 


\subsection{Case study 2}

Table 4 gives key annual RIM data for this intensive poultry (egg production) farm in the Umgeni municipal district with a real market value of R8 232000 . Table 5 summarises the annual land taxes that this farm would pay on this market value at rates from 0.25 per cent to 5 per cent, including the 1 per cent rate currently applied by the Umgeni Municipality (The Witness, 2007). Case Study 2 also qualifies for a 70 per cent land tax rebate under the GRPF guidelines (again there is no permanent housing for farm workers).

Table 4

Key measures: Intensive poultry farm (egg production), Umgeni municipality, KZN (2006=100)

\begin{tabular}{|l|c|c|c|c|c|c|}
\hline Measure & $\mathbf{2 0 0 6}$ & $\mathbf{2 0 0 5}$ & $\mathbf{2 0 0 4}$ & $\mathbf{2 0 0 3}$ & \multicolumn{1}{c|}{$\mathbf{2 0 0 2}$} & Mean \\
\hline Nominal accounting profit (R) & 1995217 & 780664 & 1496271 & 708478 & 518905 & 1099907 \\
\hline $\begin{array}{l}\text { Real accounting profit before } \\
\text { income tax (R) }\end{array}$ & 1995217 & 817449 & 1619341 & 777693 & 602677 & 1162475 \\
\hline $\begin{array}{l}\text { Real accounting profit (loss) } \\
\text { after income tax (R) }\end{array}$ & 1240130 & 524451 & 1001547 & 488823 & 314735 & 713937 \\
\hline $\begin{array}{l}\text { Real opportunity cost of } \\
\text { management (R) }\end{array}$ & 1140000 & 1140000 & 1140000 & 1140000 & 1140000 & 1140000 \\
\hline Real economic profit (R) & 100130 & -615549 & -138453 & -651177 & -825265 & -426063 \\
\hline Return to risk and land (\%) ${ }^{2}$ & $1.22 \%$ & $-7.48 \%$ & $-1.68 \%$ & $-7.91 \%$ & $-10.03 \%$ & $-5.18 \%$ \\
\hline
\end{tabular}

${ }^{2}$ Note: Real economic profit/real value of land and fixed improvements (R8 232 000).

\section{Table 5}

Annual land tax payable with and without a rebate: Intensive poultry farm (egg production), Umgeni municipality, KZN (2006=100)

\begin{tabular}{|l|c|c|c|c|c|c|c|}
\hline Land tax rate & $\mathbf{0 . 2 5 \%}$ & $\mathbf{0 . 5 \%}$ & $\mathbf{1 \%}$ & $\mathbf{2 \%}$ & $\mathbf{3 \%}$ & $\mathbf{4 \%}$ & $\mathbf{5 \%}$ \\
\hline $\begin{array}{l}\text { Amount payable } \\
\text { (No rebate) }\end{array}$ & 20580 & 41160 & 82320 & 164640 & 246960 & 329280 & 411600 \\
\hline $\begin{array}{l}\text { Amount payable } \\
(70 \% \text { rebate) }\end{array}$ & 6174 & 12348 & 24696 & 49392 & 74088 & 131712 & 123480 \\
\hline $\begin{array}{l}\text { Amount payable } \\
(50 \% \text { rebate) }\end{array}$ & 10290 & 20580 & 41160 & 82320 & 123480 & 164640 & 205800 \\
\hline
\end{tabular}

Land tax rates of between 0.25 per cent and 1 per cent with or without rebates could be funded from current operating returns only in one of the five years (2006). A land tax rate of 2 per cent with rebates could also be financed only in 2006 , when it would cut the surplus available for new investment after paying the land tax to below 1 per cent of the market value of land and fixed improvements. A land tax rate of 3 per cent with a 70 per cent rebate gives similar results to the land tax rate of 2 per cent with rebates.

\subsection{Case study 3}

Table 6 and Table 7 show the key annual accounting, economic and land tax data for this intensive dairy farm in the Umgeni municipal district (market value of R8 17800 ) that has a 70 per cent land tax rebate using the GRPF criteria (again farm workers receive no permanent housing). Annual land taxes at rates from 0.25 per cent to 2 per cent - all with and without the GRPF or Umgeni Municipality rebates - could be financed from current operating returns only 
in two of the five years (2003 and 2004). Payment of a 1 per cent annual land tax without rebates, or a 2 per cent annual land tax with the 50 per cent municipal rebate, in 2004 would have left a surplus for annual reinvestment of less than $\mathrm{R} 1000$. The mean economic profit and return to risk and land for 2001-2005 were both positive, being R6 479 and 0.08 per cent, respectively. This suggests that an annual land tax rate of 1 per cent of the market value of land and fixed improvements would markedly reduce the incentive to invest in future improvements.

Table 6

Key measures: Intensive dairy farm, Umgeni municipality, KZN (2006=100)

\begin{tabular}{|l|c|c|c|c|r|r|}
\hline Measure & \multicolumn{1}{|c|}{$\mathbf{2 0 0 5}$} & $\mathbf{2 0 0 4}$ & $\mathbf{2 0 0 3}$ & $\mathbf{2 0 0 2}$ & \multicolumn{1}{c|}{$\mathbf{2 0 0 1}$} & Mean \\
\hline Nominal accounting profit (R) & 460732 & 774047 & 1660214 & 417591 & 11278 & 664772 \\
\hline $\begin{array}{l}\text { Real accounting profit before } \\
\text { income tax (R) }\end{array}$ & 482442 & 837713 & 1822408 & 485007 & 14294 & 728373 \\
\hline $\begin{array}{l}\text { Real accounting profit (loss) } \\
\text { after income tax (R) }\end{array}$ & 323465 & 532558 & 1115645 & 299004 & 11721 & 456479 \\
\hline $\begin{array}{l}\text { Real opportunity cost of } \\
\text { management (R) }\end{array}$ & 450000 & 450000 & 450000 & 450000 & 450000 & 450000 \\
\hline Real economic profit (R) & -126535 & 82558 & 665645 & -150996 & -438279 & 6479 \\
\hline Return to risk and land (\%)3 & $-1.55 \%$ & $1.01 \%$ & $8.14 \%$ & $-1.85 \%$ & $-5.36 \%$ & $0.08 \%$ \\
\hline
\end{tabular}

${ }^{3}$ Note: Real economic profit/real value of land and fixed improvements (R8 178 000)

\section{Table 7}

Annual land tax payable with and without a rebate: Case study 3, Umgeni municipality, KZN (2006=100)

\begin{tabular}{|l|c|c|c|c|c|c|c|}
\hline Land tax rate & $\mathbf{0 . 2 5 \%}$ & $\mathbf{0 . 5 \%}$ & $\mathbf{1 \%}$ & $\mathbf{2 \%}$ & $\mathbf{3 \%}$ & $\mathbf{4 \%}$ & $\mathbf{5 \%}$ \\
\hline $\begin{array}{l}\text { Amount payable } \\
\text { (No rebate) (R) }\end{array}$ & 20445 & 40890 & 81780 & 163560 & 245340 & 327120 & 408900 \\
\hline $\begin{array}{l}\text { Amount payable } \\
(70 \% \text { rebate) (R) }\end{array}$ & 6134 & 12267 & 24534 & 49068 & 73602 & 98136 & 122670 \\
\hline $\begin{array}{l}\text { Amount payable } \\
(50 \% \text { rebate) (R) }\end{array}$ & 10223 & 20445 & 40890 & 81780 & 122670 & 163560 & 204450 \\
\hline
\end{tabular}

\subsection{Case study 4}

Key annual measures relating to the rental income earned by the lessor in Case Study 4 from leasing out 239ha of land worth R1 964487 for vegetable and maize production and grazing are shown in Table 8 . This farm would qualify for a 65 per cent land tax rebate under the GRPF criteria. Case Study 4 differs from the other four cases in estimating annual real economic profit, as the lessor receives cash rent (nominal economic profit) rather than accounting profit as annual income. The implicit assumption in this case study, therefore, is that the opportunity cost of management has been met, leaving nominal economic profit as the return to risk and land before income tax. Land maintenance costs were subtracted from nominal economic profit before charging income tax to reflect the lessor's tax-deductible expenditure in maintaining the leased land. Real economic profit after income tax thus shows the equivalent estimated annual return to risk and land. 


\section{Table 8}

Key measures: Leased land, Umgeni municipality, KZN (2006=100)

\begin{tabular}{|l|c|c|c|c|c|c|}
\hline Measure & $\mathbf{2 0 0 6}$ & $\mathbf{2 0 0 5}$ & $\mathbf{2 0 0 4}$ & $\mathbf{2 0 0 3}$ & $\mathbf{2 0 0 2}$ & Mean \\
\hline $\begin{array}{l}\text { Nominal cash rent (economic } \\
\text { profit) before income tax (R) }\end{array}$ & 84000 & 84000 & 84000 & 79000 & 79000 & 82000 \\
\hline $\begin{array}{l}\text { Annual nominal maintenance } \\
\text { costs (R) }\end{array}$ & 17000 & 15350 & 16000 & 14350 & 12750 & 15090 \\
\hline $\begin{array}{l}\text { Real economic profit before } \\
\text { income tax (R) }\end{array}$ & 67000 & 71885 & 73593 & 70966 & 76945 & 72078 \\
\hline $\begin{array}{l}\text { Real economic profit (loss) } \\
\text { after income tax (R) }\end{array}$ & 54940 & 58946 & 60066 & 57932 & 57172 & 57811 \\
\hline Return to risk and land (\%)4 & $2.80 \%$ & $3.00 \%$ & $3.06 \%$ & $2.95 \%$ & $2.91 \%$ & $2.94 \%$ \\
\hline
\end{tabular}

${ }^{4}$ Note: Real economic profit after income tax/real value of land and fixed improvements (R1 964 487).

Given the annual land taxes estimated in Table 9 , economic profit could fund rates from 0.25 per cent to 1 per cent with and without rebates in all five years during 2002-2006. However, the limited surplus available for reinvestment relative to the market value of land and fixed improvements at land tax rates of 2 per cent and greater, even with the 50 per cent rebate proposed by the Umgeni Municipality, would markedly reduce the incentive to make further capital improvements on this farm land.

\section{Table 9}

Annual land tax payable with and without a rebate: Leased land, Umgeni municipality, KZN (2006=100)

\begin{tabular}{|l|c|c|c|c|c|c|c|}
\hline Land tax rate & $\mathbf{0 . 2 5 \%}$ & $\mathbf{0 . 5 \%}$ & $\mathbf{1 \%}$ & $\mathbf{2 \%}$ & $\mathbf{3 \%}$ & $\mathbf{4 \%}$ & $\mathbf{5 \%}$ \\
\hline $\begin{array}{l}\text { Amount payable } \\
\text { (No rebate) (R) }\end{array}$ & 4911 & 9822 & 19645 & 39290 & 58935 & 78579 & 98224 \\
\hline $\begin{array}{l}\text { Amount payable } \\
(65 \% \text { rebate) (R) }\end{array}$ & 1719 & 3438 & 6876 & 13751 & 20627 & 27503 & 34379 \\
\hline $\begin{array}{l}\text { Amount payable } \\
(50 \% \text { rebate) (R) }\end{array}$ & 2456 & 4911 & 9822 & 19645 & 29467 & 39290 & 49112 \\
\hline
\end{tabular}

\subsection{Case study 5}

This mixed enterprise farm with an estimated real market value of R3 597000 qualifies for a 70 per cent land tax rebate using the GRPF guidelines (again no permanent housing is provided). Tables 10 and 11 summarise the relevant annual accounting, economic and land tax data. Case Study 5 could not pay any level of annual land tax out of annual current operating returns during 2002-2006. The negative mean annual rate of return to risk and land ( -8.50 per cent) implies that the land tax would further worsen this farm's already weak liquidity position. 


\section{Table 10}

Key measures: Mixed enterprise farm, Umgeni municipality, KZN, $(2006=100)$

\begin{tabular}{|l|c|c|c|c|c|c|}
\hline Measure & $\mathbf{2 0 0 6}$ & $\mathbf{2 0 0 5}$ & $\mathbf{2 0 0 4}$ & $\mathbf{2 0 0 3}$ & $\mathbf{2 0 0 2}$ & Mean \\
\hline $\begin{array}{l}\text { Nominal accounting } \\
\text { profit (R) }\end{array}$ & 371917 & -169792 & -196786 & 226080 & -149675 & 16349 \\
\hline $\begin{array}{l}\text { Real accounting profit } \\
\text { before income tax (R) }\end{array}$ & 371917 & -177792 & -212972 & 248167 & -173838 & 11096 \\
\hline $\begin{array}{l}\text { Real accounting profit } \\
\text { (loss) after income tax (R) }\end{array}$ & 265589 & -177792 & -212972 & 171100 & -173838 & -25583 \\
\hline $\begin{array}{l}\text { Real opportunity cost of } \\
\text { management (R) }\end{array}$ & 280000 & 280000 & 280000 & 280000 & 280000 & 280000 \\
\hline Real economic profit (R) & -14411 & -457792 & -492972 & -108900 & -453838 & -305583 \\
\hline $\begin{array}{l}\text { Return to risk and land } \\
(\%)^{5}\end{array}$ & $-0.40 \%$ & $-12.731 \%$ & $-13.71 \%$ & $-3.03 \%$ & $-12.62 \%$ & $-8.50 \%$ \\
\hline
\end{tabular}

${ }^{5}$ Note: Real economic profit/real value of land and fixed improvements (R3 597 000).

\section{Table 11}

Annual land tax payable with and without a rebate: Mixed enterprise farm, Umgeni municipality, KZN (2006=100)

\begin{tabular}{|l|c|c|c|c|c|c|c|}
\hline Land tax rate & $\mathbf{0 . 2 5 \%}$ & $\mathbf{0 . 5 \%}$ & \multicolumn{1}{c|}{$\mathbf{1 \%}$} & $\mathbf{2 \%}$ & $\mathbf{3 \%}$ & \multicolumn{1}{c|}{$\mathbf{4 \%}$} & $\mathbf{5 \%}$ \\
\hline $\begin{array}{l}\text { Amount payable } \\
\text { (No rebate) (R) }\end{array}$ & 8993 & 17985 & 35970 & 71940 & 107910 & 143880 & 179850 \\
\hline $\begin{array}{l}\text { Amount payable } \\
(70 \% \text { rebate) (R) }\end{array}$ & 2698 & 5396 & 10791 & 21582 & 32373 & 43164 & 53955 \\
\hline $\begin{array}{l}\text { Amount Payable } \\
(50 \% \text { rebate) (R) }\end{array}$ & 4497 & 8993 & 17985 & 35970 & 53955 & 71940 & 89925 \\
\hline
\end{tabular}

\subsection{Summary of results}

The estimated mean annual rate of return to risk and land (real economic profit (loss) excluding capital gains, divided by the real market value of land and fixed improvements) for the five case study farms during 2001-2006 ranged from -8.50 per cent to 2.94 per cent, with an average of -1.740 per cent. The five case study farms' ability to pay annual land taxes of between 0.25 per cent and 1 per cent of the value of improved land with and without proposed GRPF rebates from annual current operating returns ranged from zero to five out of five years, with an average of two out of five years. A land tax rate of 2 per cent with such rebates could be financed using current operating returns also only in two out of five years on average. These results suggest that annual land taxes on the market value of land and fixed improvements at rates of 1.5 per cent or 1 per cent proposed by the municipalities concerned would markedly reduce the incentive to make future capital investments on these specific farms.

\section{7}

\section{Conclusions}

Using the RIM framework, study results show that an annual land tax at the proposed rate of 1.5 per cent on the market value of improved land for Case Study 1 in the Mtonjaneni Municipality could only be financed by current 
operating returns with or without the proposed GRPF rebates in three out of five years. For case studies 2 to 5 in the Umgeni Municipality, only one farm could, on average, pay the proposed annual rate of 1 per cent with or without rebates out of current operating returns during 20012006. These findings, together with the case study farms' inability to also consistently pay these proposed annual rates or lower annual rates of 0.25 per cent over a five-year period, raise concerns about the negative impact of such rates on future investment in farm improvements, and hence, food production and prices. Given that annual land tax rates in the countries that are South Africa's major trading partners tend to be less than 1 per cent, and that most of these countries give considerably more support to agriculture, land tax rates over 1 per cent in South Africa will likely further reduce the competitiveness of the SA agricultural sector.

Study results relate to five case study farms that, while operating typical farm enterprises found in KZN, are not a statistically representative sample of commercial farms in KZN. Further research is, therefore, needed in KZN and other SA provinces to estimate how different annual rates of land tax will affect the economic performance of farms in other areas to assess whether rates above 1 per cent can be met from current operating returns without markedly reducing investment in capital improvements. Another policy issue raised by this study is the extent to which SA municipalities will adopt the DPLG GRPF guidelines on land tax rebates for commercial farms. These guidelines are not binding on municipalities, and at the time of writing, the Mtonjaneni Municipality had offered no rebate, while the Umgeni Municipality had proposed a flat rate of 50 per cent on all farm properties (despite this study showing that the four farms in the Umgeni Municipality would qualify for rebates of between 65 per cent and 70 per cent under the GRPF criteria). Given the lack of published peer-reviewed studies on how these guidelines will affect SA commercial farmers, it is critical that accurate information on the contribution of agriculture in individual municipalities be compiled. This will help municipal representatives to better assess the costs and benefits of different land tax rates and hence set affordable rates that will generate revenue without compromising future investments in farm improvements and the role of agriculture in the local economy.

This paper also highlights the need to assess the impact of land taxes on SA farms on a caseby-case, municipality-by-municipality basis, using data that are specific to individual farms. Key determinants will be the estimated market value of improved farm land, the rate randage, the extent of land tax rebates, the phasing-in period (if any) and the estimated annual current operating returns to farm land over several years. More research is needed to assess whether or not the costs that local municipalities will incur to implement land taxes (the value of rebates plus land valuation and administration costs) will be less than the revenue that they receive from these taxes. Further research could also focus on how a rural land tax may affect land use patterns and investments by commercial farmers in items such as labour training and fire control that currently reduce the costs incurred by municipalities to provide such services.

\section{Acknowledgements}

The authors would like to thank the National Research Foundation (NRF), South Africa for financing this study under the Grant Programme "Economic Growth and International Competitiveness" (GUN 2054254). The authors also thank two anonymous reviewers for their very useful comments that have improved this paper. All conclusions and recommendations expressed in this paper are those of the authors and are not to be attributed to the NRF or to the two anonymous reviewers.

\section{References}

1 AGGARWAL, R. (2001) "Using economic profit to assess performance: A metric for modern firms", Business Horizons, (January/February): 55-60.

2 BARNARD, C.S. \& NIX, J.S. (1979) Farm Planning and Control ( $4^{\text {th }}$ ed.) Cambridge University Press: Cambridge.

3 BARNSLEY, R. (2006) Personal communication, Chairman: KwaZulu-Natal Agricultural Union, Dargle, South Africa. 
4 BARRY, P.J.; ELLINGER, P.N.; HOPKIN, J.A. \& BAKER, C.B. (2000) Financial Management in Agriculture (6 $6^{\text {th }}$ ed.) The Interstate Publishers \& Printers: Danville, Illinois, USA.

5 DARROCH M.A.G. (2003) "The potential effects of a land tax on agricultural land use, investment and land values in KwaZulu-Natal”. A Report prepared for the KwaZulu-Natal Agricultural Union. Pietermaritzburg.

6 DOLL, J.P. \& ORAZEM, F. (1984) Production Economics: Theory with Applications (2 ${ }^{\text {nd }}$ ed.) Wiley: New York.

7 DEPARTMENT: PROVINCIAL AND LOCAL GOVERNMENT (DPLG) (2004a) "Local Government: Municipal Property Rates Act No. 6 of 2004”, Department: Provincial and Local Government, Republic of South Africa. http://dplg. gov.za [Accessed on 30 May 2006].

8 DEPARTMENT: PROVINCIAL AND LOCAL GOVERNMENT (DPLG) (2004b) "Guidelines on valuations for municipalities", Department: Provincial and Local Government, Republic of South Africa. http://dplg.gov.za [Accessed on 30 May 2006].

9 DEPARTMENT: PROVINCIAL AND LOCAL GOVERNMENT (DPLG) (2004c) "Generic rates policy format”, Department: Provincial and Local Government, Republic of South Africa. http://dplg. gov.za [Accessed on 30 May 2006].

10 FAUL, M.A.; EVERINGHAM, G.K.; REDELINGHUYS, H.F. \& VAN VUUREN, L.M. (1981) Financial Accounting, Butterworth: Pretoria.

11 FRANZSEN, R.C.D. (1995) "Viability of a rural land tax in South Africa", Property Management, 13(3): 21-42.

12 FRANZSEN, R.C.D. (2000) "Local government and property tax reform in South Africa", http:// www.lincolninst.edu/pubs/pub-detail.asp? $\mathrm{id}=299$ [Accessed on 13 July 2006].

13 HAWAWINI, G.; SUBRAMANIAN, V. \& VERDIN, P. (2001) "Is performance driven by industry- or firm-specific factors?", Working Paper, INSEAD Business School, Fontainebleau, France.

14 KAY, R.D. \& EDWARDS, W.M. (1999) Farm Management ( $4^{\text {th }}$ ed.) McGraw-Hill: New York.

15 LEE, C.R. (2007) Personal communication, Legal Representative for the KwaZulu-Natal Agricultural Union, Dargle, South Africa.

16 LINDHOLM, R.W. (1972) "Twenty-one land value taxation questions and answers", The American Journal of Economics and Sociology, 31(2):153-164.

17 MEPHAM, M.J. (1980) "The residual income debate", Journal of Business Finance \& Accounting, 7(2): 183-199.
18 NIEUWOUDT, W.L. (1990) "Efficiency of land use", Agrekon, 29(4): 210-214.

19 NIEUWOUDT, W.L. (1995) "The impact of a land tax on future investments: A note", The South African Journal of Economics, 63(1): 85-90.

20 O'HANLON, J. \& PEASNELL, K. (2004) "Residual income valuation: Are inflation adjustments necessary?", Review of Accounting Studies, 9: 375-398.

21 OLSEN, K.D. (2004) Farm Management: Principles and Strategies Iowa State Press: Iowa, United States of America.

22 ORGANIZATION FOR ECONOMIC COOPERATION AND DEVELOPMENT (OECD) (2006) Agricultural policies in OECD countries at a glance: 2006 Food, Agriculture and Fisheries Directorate, Organization for Cooperation and Development: Paris, France.

23 ORTMANN, G.F. (1987) "Land rents and production costs in the South African Sugar Industry", The South African Journal of Economics, 55(3): 249-258.

24 PASOUR, E.C. (1973) "Real property taxes and farm real estate values in North Carolina", American Journal of Agricultural Economics, 55: 549-556.

25 PASOUR, E.C. (1975) "The capitalization of real property taxes levied on farm real estate", American Journal of Agricultural Economics, 57: 389-397.

26 SOUTH AFRICAN DEPARTMENT OF AGRICULTURE (2006) "Price indices of machinery, trucks and implements", http://www. nda.agric.za [Accessed on 8 March 2007].

27 SOUTH AFRICAN GOVERNMENT GAZETTE (2005) Gazette No. 27720, Government Printer: Pretoria.

28 SOUTH AFRICAN REVENUE SERVICE (2006) "Income tax tables 2001-2006", http://sars. co.za [Accessed on 5 March 2007].

29 STATISTICS SA (2006) "The consumer price index and annual inflation rate on a monthly basis", http://statssa.co.za.com [Accessed on 23 November 2006].

30 THE WITNESS (2007) "Umgeni lowers rates randage", The Witness 2 June 2007: 4.

31 VAN SCHALKWYK, H.D.; VAN ROOYEN, C.J. \& JOOSTE, A. (1994) "Possible effects of an agricultural land tax in South Africa", Agrekon, 33(4): 206-211.

32 WIKIPEDIA (2006) “KwaZulu-Natal”, http:// en.wikipedia.org/wiki/KwaZulu-Natal [Accessed on 10 November 2006] 


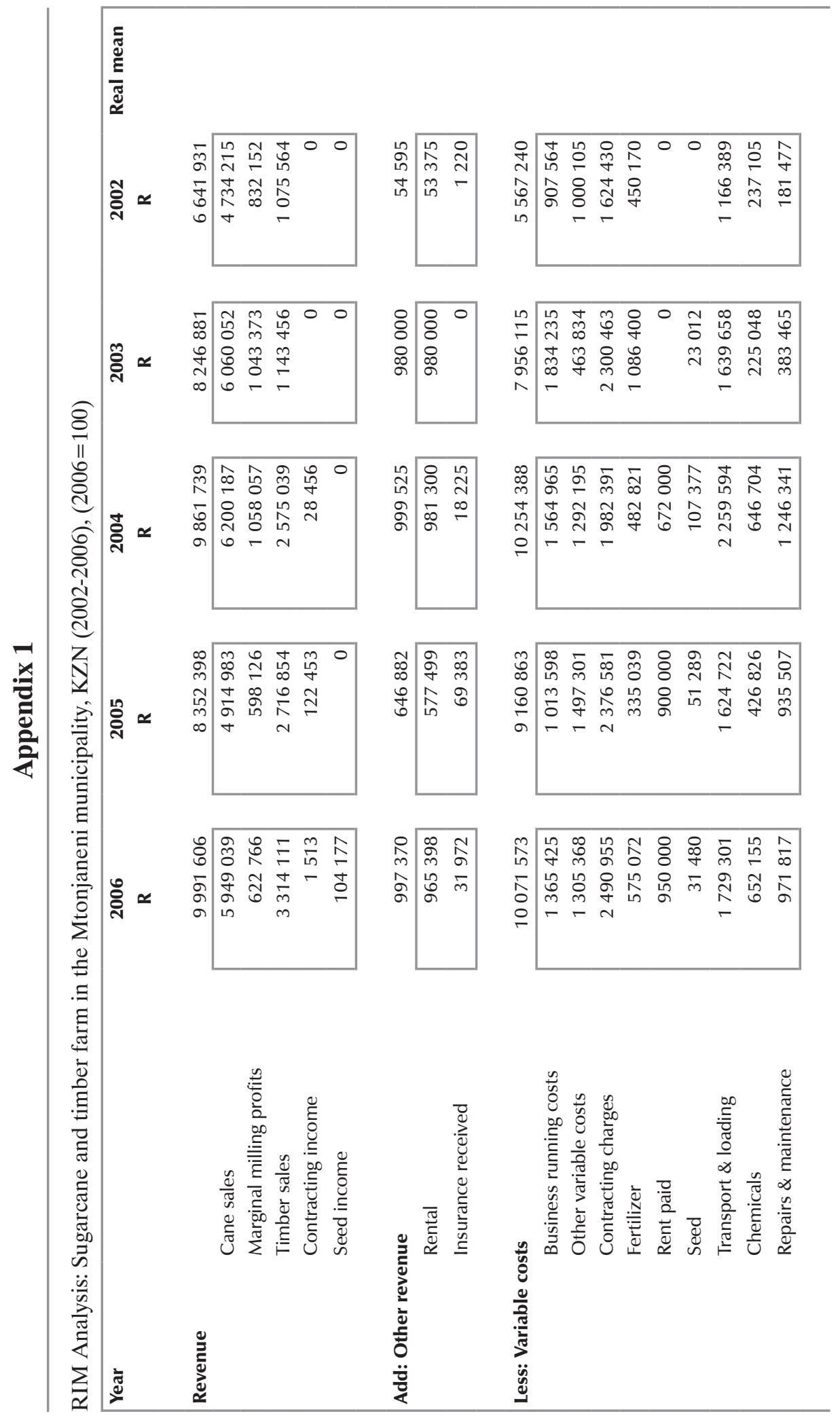




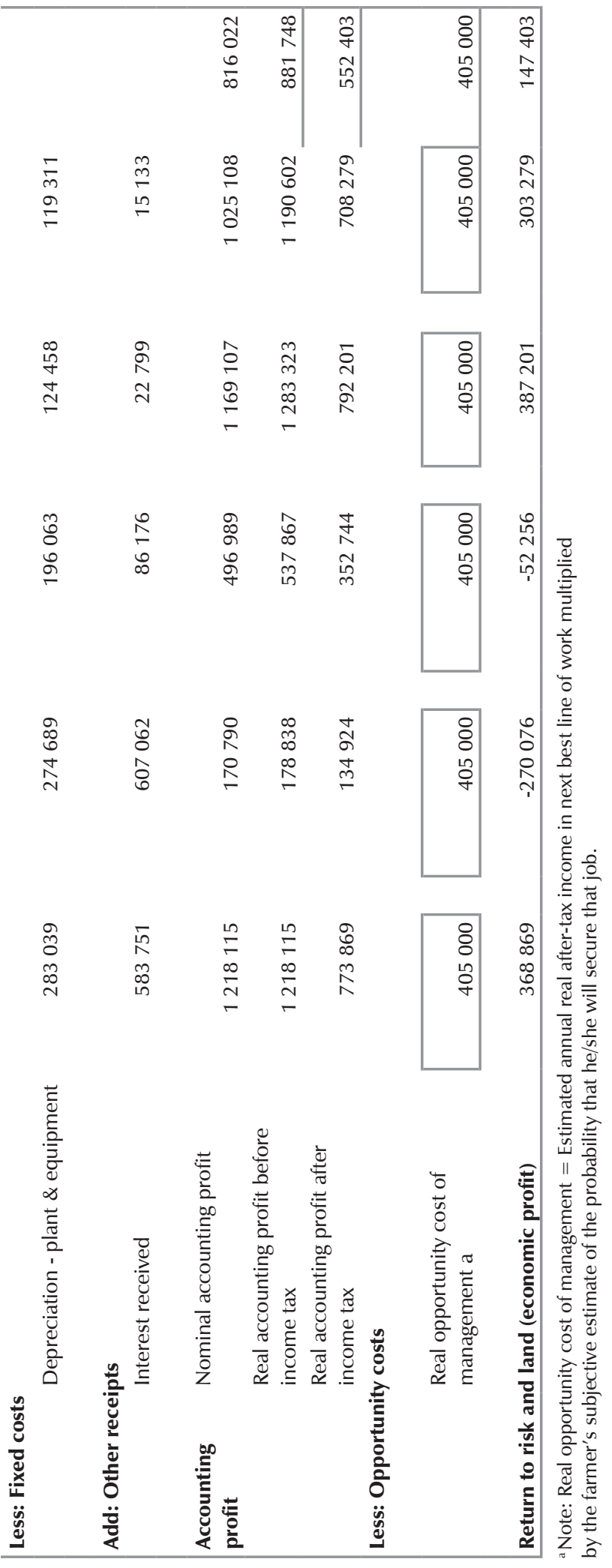




\title{
CALL FOR PAPERS: SA JoURNAL OF ECONOMIC AND Management STUdies (SAJEMS) ${ }^{1}$
}

\section{SPECIAL ISSUE: NEW FRONTIERS IN STRATEGY}

\author{
Guest Editor Johan Hough (jhough@sun.ac.za) University of Stellenbosch \\ Co-editor: $\quad$ Ernst Neuland (mwneulnd@mweb.co.za) Institute for Business Innovation \\ Co-editor: Marius Pretorius (Marius.Pretorius@up.ac.za) University of Pretoria \\ Co-editor: $\quad$ Paul Sulcas (psulcas@gsb.uct.ac.za) University of Cape Town
}

\section{Submission Deadline: September 15, 2008}

A central focus of strategic management research and practice has been the development of concepts, models and tools to guide effective market-based, competitive strategies. Today, however, strategists face mounting external pressures from increasingly mobile, influential, new media savvy and demanding stakeholders. These increasingly diverse and changing groups of stakeholders are having a greater impact on competitive and corporate level strategies and on the practices of strategic management. These influences no longer are localized in their impact. They are felt on national, regional and global levels. Consequently, on-market strategies are being employed in an ever widening circle of market settings: agriculture, airlines, autos, bio-tech, chemicals, food processing, e-commerce, entertainment, natural resources, pharmaceuticals, retail, etc.

Trends of globalization of capital flows are increasingly expanding the influence of non-financial stakeholders (e.g., political, social, regulatory, legal) over company policy. These stakeholders also affect and shape performance expectations. In large public corporations, strategic plans are increasingly developed for consumption by non-market forces where the strategy discourse reflects non-market considerations. The time is ripe for an open and critical debate about the impact of strategies on strategic actions, competitiveness and performance.

\section{Types of Papers for this SAJEMS Special Issue}

This special issue aims at providing an opportunity for debate on the above-mentioned and related topics. We invite papers, including case studies, with different theoretical concepts, frameworks and methodologies, both empirical and theory-building. As this topic lies at the intersection of several subject domains, papers can draw from several fields, such as Strategy, Innovation, International Business, and Technology. Aspects of the phenomenon can also encompass other areas such as Entrepreneurship, Operations Research, Marketing, Finance, HR and Organisational Behaviour.

\section{Examples of Sub Topics that May Be Included in this SAJEMS Special Issue}

This special issue seeks to explore themes such as the ones shown below. The list below is not meant to be exhaustive, and authors are welcome to contribute papers with other perspectives as well.

- How can operational performance and benchmarking add to strategy implementation and competitiveness?

- How to implement Blue Ocean strategies through effective leadership and teamwork

- How can companies create and capture new markets by using Strategic Maps and other implementation tools?

\footnotetext{
${ }^{1}$ SAJEMS is an ISI accredited journal
} 
- Why are companies considering the off-shoring and/or outsourcing of core functions that comprise a firm's competitive advantage?

- What role do emerging markets like South Africa, India, Brazil, China, etc and/or emerging market firms play in the global outsourcing/off-shoring phenomenon?

- What precautionary mechanisms are being put into place to protect proprietary knowledge and capabilities of the firm to prevent the loss of future competitiveness?

- What is the role of global mergers and acquisitions and strategic alliances to ensure sustainable competitiveness?

- Business ethics and corporate governance as part of organisational strategy

- Strategic planning in knowledge-based industries and ventures

- Ownership, management and operational issues in family businesses

- Issues of particular significance to the future of South Africa including BBBEE, HIV/Aids, SME's, Triple Bottom Line

\section{Guidelines and Timeline for this SAJEMS Special Issue}

All manuscripts should be prepared according to SAJEMS "Instructions to authors" (See Appendix for these Instructions). Please submit manuscripts (not under review elsewhere) in electronic MSWord format to sajems@up.ac.za.

Deadline for papers for this SAJEMS Special Issue: September 29, 2008

Decision on acceptances for this SAJEMS Special Issue: March 15, 2009 